\section{JURNAL ABDIMAS

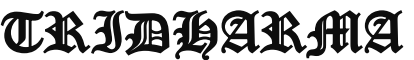 \\ AtA}

P-ISSN 2615-6849, E-ISSN 2622-3686

Jurnal ABDIMAS Vol. 2, No. 2, April 2021 Hal (39-46)

@ Prodi Manajemen Fakultas Ekonomi Universitas Pamulang

Email: abdimasjurnal.unpam@gmail.com Telp: (021) 741-2566

\title{
PENERAPAN 3M DAN HUBUNGANNYA DALAM MENINGKATKAN KINERJA KARYAWAN
}

\author{
Krisnaldy, Anita, Rita, Anis Nurrahman, \\ Syifa Iklimatul Husna, Dede Sulastri \\ Dosen Dan Mahasiswa Prodi Manajemen Fakultas Ekonomi Universitas Pamulang \\ Email : Dosen01890@unpam.ac.id, its.anita7@gmail.com, ritafebriana07@gmail.com, \\ anisnurrahman02@gmail.com, syifaiklimatulhusna@gmail.com, dedesulastri658@gmail.com
}

\begin{abstract}
ABSTRAK
Tujuan dari kegiatan Pengabdian Kepada Masyarakat ini adalah untuk melaksanakan salah satu Tri Dharma Perguruan Tinggi. Selain itu, melalui kegiatan Pengabdian Kepada Masyarakat ini, keberadaan perguruan tinggi diharapkan dapat memberikan pemahaman dan penerapan mengenai 3M di era pandemi dalam meningkatkan kinerja karyawan.

Metode kegiatan yang digunakan adalah tim pelaksana mengunjungi PT. Abisatya Panca Nawa yang beralamat di Ruko Cordoba blok F No. 10 BSD, Tangerang Selatan dan memberikan pelatihan pada Hari Rabu tanggal 17 Februari 2021. Pelatihan ini bertujuan agar karyawan dapat memahami pentingnya penerapan 3M dalam meningkatkan kinerja karyawan, terutama sebagai bekal dalam menghadapi virus di era pandemi covid-19 sekarang ini.

Hasil kegiatan Pengabdian Kepada Masyarakat ini adalah bertambahnya keilmuan mengenai cara penerapan 3M yang baik dan benar, khususnya di bidang kesehatan yaitu menggunakan masker dengan baik, mencuci tangan dengan baik dan menjaga jarak di masa pandemi seperti sekarang ini.

Ilmu yang didapatkan pada kegiatan Pengabdian Kepada Masyarakat ini diharapkan karyawan mampu menerapkan 3M dengan baik dan benar di Kantor maupun diluar Kantor untuk mengantisipasi tertularnya virus covid-19.
\end{abstract}

\section{Kata kunci : Penerapan 3M, Kinerja Karyawan.}

\section{ABSTRACT}

The purpose activity is to carry out one of the obligations of the Tri Dharma Perguruan Tinggi. In addition, through this activity, the existence of university is expected to to provide understanding and application of $3 M$ in the pandemic era in improving employee performance. $\downarrow$.

The activity method used was the implementation team visiting PT. Abisatya Panca Nawa, having his address at Ruko Cordoba block F No. 10 BSD, Tangerang Selatan and provided training on Wednesday, February 17, 2021. This training aims so that employees can understand the importance of implementing $3 M$ in improving employee performance, especially as provisions for dealing with the virus in the current Covid-19 pandemic era.

The result of this activity is the increase in regarding the proper and correct way of implementing $3 M$, especially in the health sector, namely using masks properly, washing hands well and maintaining distance during a pandemic like today.

The knowledge gained in this activity is expected that employees will be able to apply $3 \mathrm{M}$ properly and correctly in the office and outside the office to anticipate contracting the covid-19 virus.

Keywords: 3M Implementation, Employee Performance. 


\section{JURNAL ABDIMAS

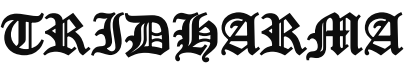

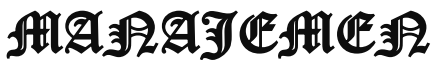

P-ISSN 2615-6849, E-ISSN 2622-3686

Jurnal ABDIMAS Vol. 2, No. 2, April 2021 Hal (39-46)

@Prodi Manajemen Fakultas Ekonomi Universitas Pamulang

Email: abdimasjurnal.unpam@gmail.com Telp: (021) 741-2566

\section{PENDAHULUAN}

Pada awal tahun 2020, terdapat jenis virus baru yang merebak dan menggemparkan seluruh dunia, yakni coronavirus jenis baru bernama SARS-CoV2 dan penyakit yang ditimbulkan dari virus tersebut disebut Coronavirus disease2019 (Covid-19) (Guan et al., 2020). Penyakit ini pertama kali ditemukan di Wuhan, Provinsi Hubei, Cina pada akhir tahun 2019 tepatnya dibulan Desember. Awal mula transmisi virus ini belum dapat ditentukan apakah terjadi antar manusia kemanusia. Namun, saat ini coronavirus masih menyebar dengan cepat pada manusia di seluruh dunia (Cherradi, 2020). Hal tersebut sangat mempengaruhi perekonomian masyarakat Indonesia. Para buruh banyak yang dirumahkan karena pabrik atau tempat mereka bekerja tidak lagi beroperasi atau ditutup untuk waktu yang belum bisa ditentukan. Karyawan pun berkurang penghasilannya karena jam kerja dipangkas untuk mengurangi penyebaran virus ini. Masyarakat yang tidak memiliki tabungan kebingungan untuk menyambung hidup karena pandemi ini sudah berlangsung berbulan-bulan. Beruntunglah orang yang mengikuti saran Allah SWT seperti tertulis dalam Al Qur'an surat Al Israa ayat 27 yang artinya: "Sesungguhnya para pemboros itu adalah saudara-saudaranya syetan." Pandemi menjadi pembelajaran bagi kita agar kita mampu melakukan perencanaan dan pengelolaan keuangan agar kita tidak hidup boros dan mempunyai simpanan untuk masa depan.

Pandemi COVID-19 di tahun 2020 berdampak luar biasa, melumpuhkan hampir semua aspek kehidupan. Semua orang diwajibkan menerapkan protokol kesehatan $3 \mathrm{M}$, yaitu memakai masker, mencuci tangan dengan sabun, dan menjaga jarak fisik dengan orang lain. Penerapan aturan ini harus terus dilaksanakan dalam setiap kegiatan, baik di dalam maupun di luar rumah. Wiku Adisasmito (Juru Bicara Satgas Penanganan COVID-19) menegaskan, bahwa kedisiplinan menerapkan protokol kesehatan 3M merupakan kontribusi masyarakat terhadap upaya penanganan COVID-19 yang dilakukan pemerintah (KPC PEN, 2020). Ini merupakan strategi terbaik pemerintah dalam upaya pencegahan dan pengendalian COVID-19, menempatkan masyarakat sebagai garda terdepan dengan perubahan perilaku sebagai ujung tombak. Sedangkan dokter, perawat, dan tenaga medis yang jumlahnya terbatas merupakan benteng terakhir pengendalian Covid-19.

Setiap hari jumlah kasus positif dan korban meninggal terus bertambah, baik dari kalangan masyarakat umum maupun tenaga medis, orang dewasa maupun anak-anak. Satgas Penanganan Covid-19 mencatat penambahan pasien positif per 7 November 2020 sebanyak 4262 orang, sehingga total jumlah kasus positif menjadi 433.836 kasus. Di Jakarta, data terkini Dinas Kesehatan Pemerintah Profinsi DKI Jakarta menyebutkan, bahwa jumlah kasus aktif naik sebanyak 441 kasus, sehingga jumlah kasus aktif sebanyak 8444 (orang yang masih dirawat / isolasi). Sedangkan jumlah kasus konfirmasi secara total di Jakarta sebanyak 125.822 kasus. Penambahan kasus dari hari per hari menggambarkan bahwa kepatuhan terhadap protokol kesehatan masih belum optimal dilaksanakan oleh masyarakat (Kemkes RI, 2020).

Berbagai pelanggaran terhadap penerapan protokol kesehatan memang masih terjadi di berbagai wilayah, walaupun razia sering dilakukan petugas. Sanksi yang diberikan belum mampu membangkitkan kesadaran warga untuk mematuhi aturan. Ketidakpatuhan ini yang membuat penularan virus semakin cepat meluas, tidak hanya meningkatkan jumlah pasien positif yang memenuhi ruangan rumah sakit, namun juga menambah jumlah korban yang wafat. Ketidakpatuhan warga seolah menjadi pemandangan keseharian, yang dianggap hal biasa terjadi di lingkungan masya rakat. Padahal, ketidakpatuhan warga adalah kunci bagi kegagalan penanganan pandemi COVID-19.

PT. Abisatya Panca Nawa merupakan salah satu Perusahaan di Tangerang Selatan 


\section{JURNAL ABDIMAS

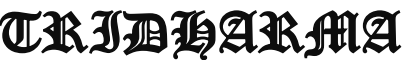 AtA}

P-ISSN 2615-6849, E-ISSN 2622-3686

Jurnal ABDIMAS Vol. 2, No. 2, April 2021 Hal (39-46)

@Prodi Manajemen Fakultas Ekonomi Universitas Pamulang

Email: abdimasjurnal.unpam@gmail.com Telp: (021) 741-2566 yang bergerak di bidang Perusahaan Elektronik, Playground. Perusahaan yang berlokasi di Ruko Cordoba Blok F No. 10, BSD Kota Tangerang Selatan. Perusahaan ini didirikan sebagai salah satu upaya memenuhi kebutuhan masyarakat di bidang manufaktur dengan memberikan harga terbaik yang sesuai dengan budget serta memberikan pelayanan yang nyaman dan menjadi sahabat dalam kebutuhan produk percetakan.

Hasil survey yang telah dilakukan terhadap beberapa karyawan perkantoran di PT. Abisatya Panca Nawa bahwa mayoritas karyawan belum mengetahui upaya preventif covid-19 di area kerja. Hasil survey yang dilakukan secara langsung juga menyatakan bahwa beberapa karyawan tidak menggunakan masker ketika berada di lingkungan kerja, masih berdekatan / tidak menjaga jarak. Selain itu beberapa karyawan menganggap bahwa penggunaan masker hanya dilakukan ketika mereka berada di luar ruangan atau ketika berhadapan/ berinteraksi dengan orang lain. Bahkan ada beberapa karyawan meyakini bahwa tidak mungkin sesama teman kerja akan membawa virus covid-19 atau menularkan virus covid-19. Berdasarkan latar belakang yang ada maka perlu dilakukan pengabdian kepada masyarakat terkait Pentingnya penerapan 3M dan hubungannya dalam meningkatkan kinerja karyawan di Area Kerja pada karyawan PT. Abisatya Panca Nawa.

\section{RUMUSAN MASALAH}

Salah satu persoalan yang dihadapi oleh PT. Abisatya Panca Nawa adalah kurangnya kesadaran karyawan dalam mematuhi protokol kesehatan dengan menerapkan 3M dalam lingkungan kantor. Hal ini berimbas pada kesehatan karyawan kantor yang tertular akan virus covid-19 tersebut. Di masa pandemi ini banyak karyawan yang kurang mematuhi protokol kesehatan mengenai covid-19 tentang penerapan 3M dilingkungan kantor.

Juru bicara pemerintah untuk penanganan Covid-19 mengatakan, pemerintah mengajak masyarakat untuk memutus mata rantai penularan Covid-
19 di masyarakat Indonesia. Beliau Kembali mengingatkan ada sejumlah Langkah yang bias dilakukan untuk memutus matarantai penularan tersebut. Kita harus berusaha untuk memutus mata rantai penularan di masyarakat, dengan cara memakai masker, menjaga jarak secara fisik minimal 1 meter dan sering mencuci tangan dengan sabun memakai air mengalir.

Anjuran mengenai penggunaan maskerbdi tengah masyarakat, selama perawatan di rumah (home care), dan di tempat pelayanan kesehatan di wilayahwilayah yang telah melaporkan kasus COVID-19. Dokumen ini diperuntukkan bagi anggota masyarakat, tenaga professional kesehatan masyarakat dan pencegahan dan pengendalian infeksi (PPI), pengelola pelayanan kesehatan, tenaga kesehatan, dan kader kesehatan. Dokumen ini akan diperbarui seiring perkembangan data.Informasi yang ada saat ini mengindikasikan bahwa dua cara utama transmisi virus COVID-19 adalah percikan (droplet) saluran pernapasan dan kontak. Percikan saluran pernapasan dihasilkan saat seseorang batuk atau bersin. Setiap orang yang berada dalam kontak erat (dalam radius $1 \mathrm{~m})$ dengan orang yang menunjukkan gejala-gejala gangguan pernapasan (batuk, bersin) berisiko terpapar percikan saluran pernapasan yang kemungkinan dapat menyebabkan infeksi (infeksius). Percikan juga dapat jatuh ke permukaan benda di mana virus tetap aktif; oleh karena itu, lingkungan sekitar terdekat dari orang yang terinfeksi dapat menjadi sumber penularan (penularan kontak). WHO baru-baru ini merangkum laporan-laporan transmisi virus COVID-19 dan memberikan gambaran singkat buktibukti yang ada tentang penularan dari orangorang bergejala (simtomatik), yang belum menunjukkan gejala (prasimtomatik), dan tidak bergejala (asimtomatik) yang terinfeksi COVID-19 (informasi lengkap tersedia dalam WHO COVID-19 Sitrep 79).

Ketidakpatuhan dalam kaitan dengan kesehatan diartikan sebagai kondisi ketika individu atau kelompok berkeinginan untuk patuh, tetapi ada sejumlah faktor yang meng hambat kepatuhan terhadap saran tentang 


\section{JURNAL ABDIMAS

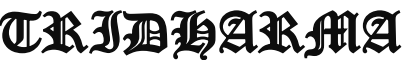 AtA}

P-ISSN 2615-6849, E-ISSN 2622-3686

Jurnal ABDIMAS Vol. 2, No. 2, April 2021 Hal (39-46)

@Prodi Manajemen Fakultas Ekonomi Universitas Pamulang

Email: abdimasjurnal.unpam@gmail.com Telp: (021) 741-2566 kesehatan yang diberikan oleh tenaga kesehatan (Prihantana \& dkk, 2016).

Ketidakpatuhan karyawan terhadap penerapan protokol kesehatan $3 \mathrm{M}$ itu sendiri dapat disebabkan beberapa faktor, salah satunya adalah sikap tidak peduli yang dianjurkan oleh Pemerintah. Hal ini diungkapkan Dicky Rachmawan, bahwa tingginya jumlah pelanggaran dan terjadi secara massif di masyarakat yang tidak hanya di satu tempat merupakan sebuah permasalahan sosial di Indonesia dalam konteks penanganan COVID-19, namun yang lebih mengkhawatirkan adalah "ketidakpedulian" atau "acuh takacuhnya" karyawan terhadap protokol kesehatan (Rachmawan, 2020).

\section{TUJUAN KEGIATAN}

Kegiatan Pengabdian Masyarakat ini bertujuan untuk menjaga protokol kesehatan 3M agar karyawan tetap dapat beraktifitas secara aman, tidak membahayakan kesehatan dan keselamatan diri sendiri maupun orang lain. Pada implementasinya, penerapan protokol kesehatan 3M ini disikapi beragam oleh karyawan, banyak yang mematuhinya dengan penuh kesadaran, namun ada pula yang tidak peduli. Ketidakpatuhan karyawan inilah yang memperburuk situasi.

\section{TINJAUAN PUSTAKA}

\section{Pandemi COVID-19}

Coronavirus Disease 2019 (COVID19) adalah penyakit menular yang disebabkan oleh Severe Acute Respiratory Syndrome Corona virus 2 (SARS-Cov-2) yang merupakan corona virus jenis baru dan belum pernah diidentifikasi sebelumnya pada manusia. Beberapa orang yang terinfeksi tidak menunjukkan gejala apapun dan tetap merasa sehat. Gejala yang paling umum adalah demam, rasa lelah, dan batuk kering. Beberapa pasien mungkin mengalami rasa nyeri dan sakit, hidung tersumbat, pilek, nyeri kepala, konjungtivitis, sakit tenggorokan, diare, hilang penciuman dan pembauan atau ruam kulit. Pada kasus COVID-19 yang berat dapat menyebabkan pneumonia, sindrom pernafasan akut, gagal ginjal, dan bahkan kematian. Gejala yang muncul di awal infeksi masih bersifat ringan dan sering diabaikan, padahal harus segera ditangani karena gejala virus ini muncul secara bertahap dengan masa inkubasi ratarata 5-6 hari dan masa inkubasi terpanjang 14 hari.

Covid-19 dapat menyerang siapa saja tanpa kecuali, termasuk anak muda. Kelompok ini memiliki imunitas yang lebih baik sehingga mungkin dapat terpapar tanpa menunjukkan gejala (asimtomatik), tetapi berbahaya dan dapat menyebabkan kematian bagi orang-orang di sekitarnya (silent killer).

Menurut WHO, kelompok yang paling banyak menyebarkan virus ini berada dalam rentang usia 20-40 tahun. Sedangkan kelompok lain yang berisiko tinggi terhadap penularan virus adalah orang berusia lanjut (usia 60 tahun ke atas), berpenyakit penyerta (komorbid), memiliki daya tahan tubuh rendah, dan yang mengalami obesitas (berat badan berlebih). COVID-19 tidak ditularkan oleh hewan, tetapi menular antarmanusia terutama dari orang-orang terdekat. Virus ini ditularkan melalui cipratan liur (droplet) yang dikeluarkan seseorang dari mulut atau hidung ketika bersin, batuk, bahkan saat berbicara. Droplet dapat jatuh dan menempel pada benda-benda di sekitar. Oleh sebab itu, ketika memegang bend-benda itu, tangan seseorang berpotensi menjadi jalur transmisi penularan COVID-19 jika menyentuh hidung, mulut, dan mata. Walaupun terbilang ganas dan mematikan, COVID-19 memiliki 2 kelemahan, yaitu: Dapat mati jika tempat hidupnya dibersihkan dengan sabun, Virus ini tahan temperatur tinggi, namun semakin tinggi temperaturnya, semakin pendek masa bertahan virus. Penyebaran virus yang semakin meluas dalam waktu sangat singkat menuntut semua pihak untuk melakukan upaya pencegahan dan penanganan yang cepat dan konsisten. Dalam kaitan itu, WHO sendiri melakukan langkah strategis, yaitu dengan merekomendasikan pemeriksaan molekuler untuk seluruh pasien yang terduga terinfeksi COVID-19. Metode yang dianjurkan adalah metode deteksi molekuler/ NAAT (Nucleic Acid Amplification Test) seperti 


\section{JURNAL ABDIMAS

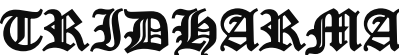 AtA}

pemeriksaan RT-PCR (Satuan Tugas Penanganan Covid-19, 2020).

\section{Pentingnya Penerapan 3M}

Protokol kesehatan 3M (memakai masker, mencuci tangan dengan sabun, dan menjaga jarak serta menjauh dari kerumunan) merupakan cara terbaik yang dapat diterapkan untuk menghentikan rantai penyebaran COVID-19. Upaya ini menuntut kedisiplinan tinggi dan harus diterapkan setiap saat secara konsisten. Hal ini sesuai dengan pernyataan World Health Organization (WHO), bahwa salah satu upaya memelihara diri agar terhindar dari penyakit ini adalah dengan rajin membersihkan tangan menggunakan sabun maupun cairan berbasis alkohol, hindari sering me nyentuh bagian wajah (mata, mulut dan hidung) serta melakukan pembatasan kontak fisik dengan orang lain (social distancing) (Wiranti, Sriatmi, \& Kusumastuti, 2020).

Cara Penerapan 3M (Memakai Masker, Mencuci Tangan, dan Menjaga Jarak) yang baik dan benar:

\section{Cara Memakai Masker yang baik dan benar:}

1. Kaitkan tali masker ketelinga

2. Posoisikan kawat masker diatas hidung

3. Tarik masker kebawah sampai menutupi mulut hingga dagu.

\section{Cara mencuci tangan yang baik dan} benar:

1. Memakai sabun

2. Menggosok kedua telapak tangan

3. Menggosok sela-sela jari

4. Menggosok ujung jari

5. Menggosok pergelangan tangan

6. Menggosok ibu jari

7. Bilas menggunakan air bersih

8. Keringkan tangan dengan kain bersih/tissue

\section{Menjaga jarak dengan baik dan benar: \\ 1. Hindari kerumunan \\ 2. Menjaga jarak minimal 1 meter}

Protokol kesehatan yang harus diterapkan oleh karyawan saat memasuki kantor:

1) Memakai masker

Memakai masker merupakan cara yang paling efektif dalam mencegah penyebaran virus corona. Masker juga dikenal dengan alat pelindung diri. Sebagai alat pelindung diri, masker dirancang untuk memberikan perlindungan kepada pemakainya dan sbukan sebaliknya menjadi sarana transmisi atau penularan karena penggunaan yang salah.

2) Mencuci tangan

Mencuci tangan merupakan cara untuk menurunkan resiko penularan covid-19. Mencuci tangan mengkin terlihat mudah dan sering diremehkan hingga dilupakan. Namun mencuci tangan merupakan sesuatu hal yang penting untuk menurunkan penularan bebagai macam virus.

3) Menjaga jarak

Menjaga jarak merupakan mencegah penularan covid-19 dari jarak dekat. Dalam menjaga jarak WHO menyarankan setidaknya 1 meter dengan orang lain hal ini di haruskan Karena agar orang tidak dapat tertular dari orang lain dari jarak dekat. Virus corona dapat menyebar terutama dari orang ke orang melaului percikanpercikan dari hidung atau mulut yang keluar saat orang terinfeksi batuk, bersin atau berbicara.

\section{Manfaat 3m bagi karyawan}

1. Membunuh ribuan bakteri

2. Masker menjaga dari covid-19

3. Jaga jarak

\section{METODE PELAKSANAAN}

Metode kegiatan pengabdian kepada masyarakat ini dibagi menjadi beberapa tahap. Tahap pertama adalah identifikasi masalah yang dilakukan sebagai langkah awal untuk merumuskan apa saja yang akan dijadikan bahan untuk perancangan sistem dan materi pelatihan dalam kegiatan pengabdian kepada masyarakat ini.

Tahap berikutnya yaitu melakukan survei lapangan PT. Abisatya Panca Nawa 


\section{JURNAL ABDIMAS

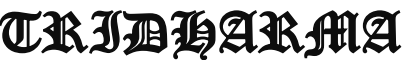 AtA}

P-ISSN 2615-6849, E-ISSN 2622-3686

Jurnal ABDIMAS Vol. 2, No. 2, April 2021 Hal (39-46)

@Prodi Manajemen Fakultas Ekonomi Universitas Pamulang

Email: abdimasjurnal.unpam@gmail.com Telp: (021) 741-2566
Ruko Cordoba Blok F No. 10, BSD Kota Tangerang Selatan. Tim pelaksana kemudian melakukan sosialisasi kepada karyawan PT. Abisatya Panca Nawa. Proses pelatihan ini membahas mengenai tentang penerapan $3 \mathrm{M}$ dan hubungan nya dalam menigkatkan kinerja karyawan. Pada tahap ini anggota tim pelaksana berdiskusi sesuai tema dan materi yang akan disampaikan, bahan dan alat yang diperlukan, serta persiapan teknis lainnya yang dibutuhkan untuk kelancaran pelaksanaan kegiatan pengabdian kepada masyarakat ini. Permasalahan yang ditemukan pada karyawan PT. Abisatya Panca Nawa ini yaitu kurangnya kesadaran akan pentingnya penerapan protokol kesehatan khususnya penerpan 3M dilingkunagn kantor.

Tahap berikutnya adalah pelaksanaan kegiatan PT. Abisatya Panca Nawa Ruko Cordoba Blok F No. 10, BSD Kota Tangerang Selatan. Kegiatan ini dilakukan dengan memberikan penyuluhan kepada karyawan agar menerapkan 3M di lingkungan kantor. Peserta yang mengikuti kegiatan ini sebanyak 5 orang. Peserta adalah Mahasiswi dari jurusan Manajemen Keuangan semester 8 .

Pihak mitra, yaitu PT. Abisatya Panca Nawa menyediakan ruang kegiatan yang memadai dan nyaman. Hal yang perlu diperhatikan yaitu cara mengatur (formasi) tempat duduk. Karena masih berada di masa pandemi, maka peserta dibatasi dan pengaturan tempat duduk serta pelaksanaan kegiatannya disesuaikan dengan protokol kesehatan (duduk diatur agar berjarak, tetap menggunakan masker, mencuci tangan setelah kegiatan, dan protokol kesehatan lainnya).

Untuk menunjang lancarnya pelaksanaan kegiatan ini, diperlukan beberapa alat bantu/media pembelajaran tertentu, yaitu :
1) LCD (Liquid Crystal Display)
2) Laptop
3) Spidol
4) White board
5) Buku catatan

Tahap terakhir dalam kegiatan pengabdian kepada masyarakat ini yaitu tindak lanjut dari pelaksanaan kegiatan ini. Pada tahap ini dilakukan diskusi atau tanya jawab tentang permasalahan seputar penerapan 3M dan hubungannya dengan meningkatkan kinerja karyawan, kemudian dilakukan simulasi mengenai materi tersebut. Kegiatan pengabdian kepada masyarakat ini bertujuan untuk membuat karyawan agar menyadari pentingnya penerapan $3 \mathrm{M}$ dalam kehidupan sehari-hari guna menekan penyebaran virus covid-19. Pengetahuan ini diharapkan dapat ditularkan pula kepada anggota keluarga mereka. Target lain yang ingin dicapai dalam kegiatan pengabdian kepada masyarakat ini adalah timbulnya motivasi dalam diri tim pelaksana kegiatan untuk membuat sebuah tulisan ilmiah terkait penerapan $3 \mathrm{M}$ dan hubungannya dalam meningkatkan kinerja karyawan di era pandemic dan mempublikasikan hasil tulisan tersebut ke dalam jurnal Pengabdian Kepada Masyarakat.

\section{HASIL DAN PEMBAHASAN \\ Hasil Kegiatan}

Berdasarkan hasil sosialisasi, tanya jawab dan pengamatan langsung selama kegiatan berlangsung, kegiatan pengabdian pada masyarakat ini memberikan hasil sebagai berikut :

a. Meningkatnya kesadaran para karyawan untuk menerapkan 3M dilingkungan kantor.

b. Meningkatnya motivasi karyawan untuk hidup sehat dalam menghadapi virus covid-19 dengan menerapkan protokol kesehatan khususnya menerapkan 3M.

\section{Faktor Pendukung dan Faktor Penghambat}

Beberapa faktor yang mendukung terlaksananya kegiatan pengabdian pada masyarakat ini adalah besarnya minat dan antusiasme peserta selama kegiatan, sehingga kegiatan berlangsung dengan lancar dan efektif. Sedangkan faktor penghambatnya adalah keterbatasan waktu pelatihan dan fasilitas peralatan yang masih minim. 


\section{JURNAL ABDIMAS

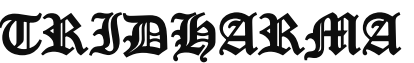

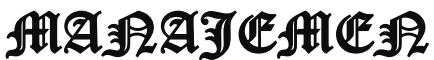

P-ISSN 2615-6849, E-ISSN 2622-3686

Jurnal ABDIMAS Vol. 2, No. 2, April 2021 Hal (39-46)

@ Prodi Manajemen Fakultas Ekonomi Universitas Pamulang

Email: abdimasjurnal.unpam@gmail.com Telp: (021) 741-2566

\section{Pembahasan}

Kegiatan Pengabdian ini dilakukan di PT. Abisatya Panca Nawa, dengan tema yang diambil adalah Penerapan $3 \mathrm{M}$ dan hubungannya dengan meningkatkan kinerja karywan. Selama pelaksanaan kegiatan, karyawan antusias mengikuti. Ketertarikan mereka dikuatkan dengan adanya partisipasi aktif baik, baik memberikan jawaban dan tanggapan dari moderator dan pemateri, maupun memberi pertanyaan kepada moderator dan pemateri. Kegiatan berlangsung dengan tertib dan lancar karena karyawan PT. Abisatya Panca Nawa sangat mendukung kegiatan ini dengan membantu menyiapkan tempat dan mengkondisikan karyawannya agar siap mengikuti kegiatan ini.

\section{KESIMPULAN DAN SARAN Kesimpulan}

Dari kegiatan pengabdian pada masyarakat ini dapat disimpulkan bahwa:

1. Pentingnya penerapan $3 \mathrm{M}$ dalam lingkungan kantor guna mencegah penyebaran virus covid-19.

2. Sejumlah upaya penanganan penularan covid-19 diperusahaan atau perkantoran sudah disiapkan. Untuk kasus pekerja yang terpapar langsung dilakukan penutupan sementara terhadap perusahannya selama 3 hari.

\section{Saran}

Mengingat besarnya manfaat kegiatan pengabdian pada masyarakat ini, maka selanjutnya perlu:

1. Bagi karyawan yang terpapar covid-19 harus dirumahkan selama 14 hari, atau dirawat dirumah sakit yang di tunjuk perusahaan atau wisma atlet.

2. Mengadakan sosialisasi dan pelatihan serupa pada karyawan perusahaan lain dengan materi yang serupa.

\section{DAFTAR PUSTAKA}

Guan W, Ni Z, Hu Y, Liang W, He J, et al. (2020). Clinical characteristics of 2019 novel coronavirus infection in China.
Kementerian Kesehatan Republik Indonesia. (2020). Pedoman dan pencegahan coronavirus disesase (COVID-19). In Math Didactic: Jurnal Pendidikan Matematika(Vol. 4, Issue Juli). Kementrian Kesehatan RI.

Kementerian Kesehatan Republik Indonesia; Gerakan Masyarakat Hidup Sehat. (2020). Apa yang harus dilakukan masyarakat untuk cegah penularan COVID-19(K. K. R. I. G. M. H. Sehat (ed.)). Kementerian Kesehatan Republik Indonesia; Gerakan Masyarakat Hidup Sehat.

Cherradi, Y. (2020). CoVID-19: a Digestive Disease! Journal of Medical and Surgical Research, 1(May), 714-721.

Pasaribu, V. L. D., Susanti, F., \& Hartuti, E. T. K. (2019). Memotivasi Siswa dan Siswi SMK Letris Indonesia di Dalam Menentukan Pilihan Untuk Melanjutkan Pendidikan Atau Bekerja Setelah Lulus Sekolah. Jurnal Pengabdian Dharma Laksana, 1(2), 161-172.

Pasaribu, V. L. D., Agrasadya, A., Shabrina, N., \& Krisnaldy, K. (2020). MENJADI ENTERPRENEUR MUDA YANG MEMILIKI JIWA LEADERSHIP UNTUK MENGHADAPI MASA DEPAN. Abdi Laksana, 1(1).

Pasaribu, V. L. D., Elburdah, R. P., Sudarso, E., \& Fauziah, G. (2020). PENGGUNAAN MANAJEMEN WAKTU TERHADAP PENINGKATAN PRESTASI BELAJAR DI SMP ARAISIYAH. Jurnal ABDIMAS Tri Dharma Manajemen, l(1).

Pasaribu, V. L. D., Sulaiman, S., Sutiman, S., Thaharudin, T., \& Purnomo, B. Y. (2020). PENGENALAN LETAK POSYANDU TERDEKAT DIKELURAHAN PISANGAN DENGAN MANAJEMEN PEMASARAN REVOLUSI 4.0 UNTUK MENINGKATKAN PENGETAHUAN MASYARAKAT LETAK DAN FUNGSI POSYANDU TERDEKAT PADA KELURAHAN PISANGAN. DEDIKASI PKM, 1(1), 105-110.

Pasaribu, V. L. D., Oktrima, B., Prabowo, B., Arianto, N., \& Haryoko, U. B. (2020). PROGAM 


\section{JURNAL ABDIMAS

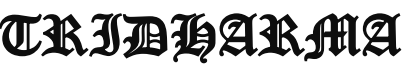

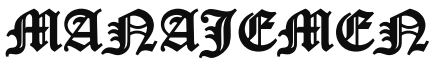

P-ISSN 2615-6849, E-ISSN 2622-3686

Jurnal ABDIMAS Vol. 2, No. 2, April 2021 Hal (39-46)

@Prodi Manajemen Fakultas Ekonomi Universitas Pamulang

Email: abdimasjurnal.unpam@ gmail.com Telp: (021) 741-2566
PENDAMPINGAN

DAN

PENYELENGGARAAN PENDIDIKAN ANAK PADA USIA DINI TERHADAP PRESTASI BELAJAR DILINGKUNGAN RT 020 RW 009. KEL GIRI PENI. KEC WATES. YOGYAKARTA. JURNAL LOKABMAS KREATIF, 1(1), 71-75.

Prihantana, dkk. (2016). Hubungan Pengetahuan Dengan Tingkat Kepatuhan Pengobatan Pada Pasien Tuberkolosis Di RSUD Dr. Soehadi Prijonegoro Sragen. Jurnal Farmasi Sains Dan Praktis. Vo. 2. No. 1. Poltekkes Bhakti Mulia.

Wiranti, Sritami, Kusumastuti. (2020). Determinan Kepatuhan Masyarakat Kota Depok Terhadap Kebijakan Pembatasan Sosial Berskala Besar Dalam Pencegahan Covid-19.

Anismadiyah v. \& dkk. (2021). Financial Planning for millennials in pandemic era.

Rachmawan, D. (2020). Oktober. Retrieved 2020, from PMB LIPI Website: http://pmb.lipi.go.id/melampauiketidak patuhan-masyarakat-kebingungan-dankeacuhan-dalam-kejenuhan-perdebatanyang-tiada-henti/.

\section{FOTO DOKUMENTASI}

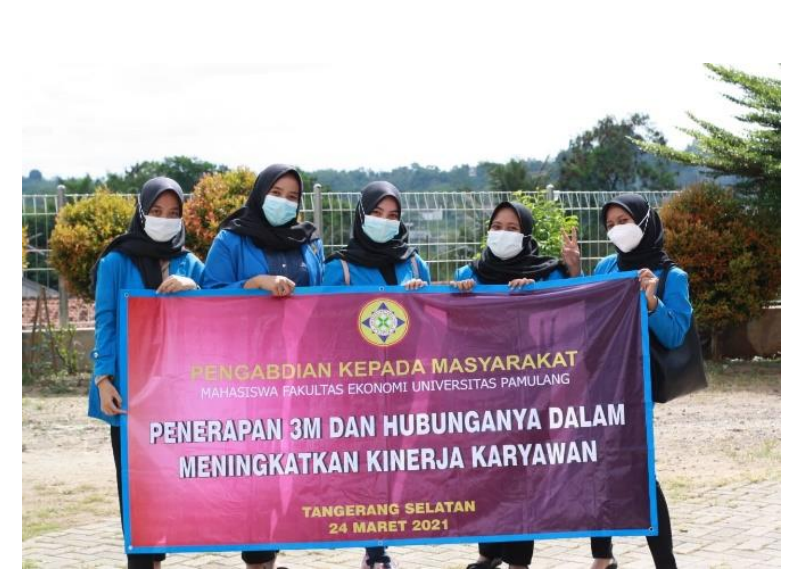

https://www.indotrading.com/abisatyapanca $\underline{\text { nawa }}$

https://akrabjuara.com/index.php/akrabjuara /article/view/1354/1182

https://www.ui.ac.id/mahasiswa-fik-ui-

edukasi-3m-covid-19-bagi-anak-sd/

https://stp-mataram.e-

journal.id/Amal/article/view/386
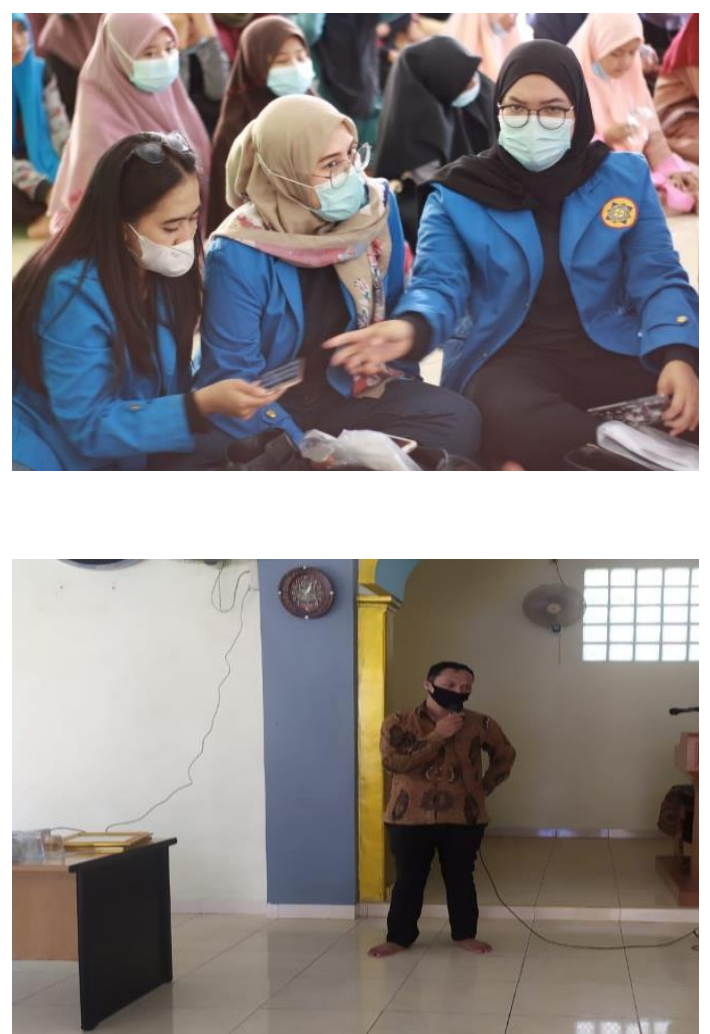